\title{
A Proton Pump, Bacteriorhodopsin, Has a Proton Channel Activity Which Is Gated by Light
}

\author{
Koki OHNO ${ }^{1)}$ and Hajime HIRATA ${ }^{2)}$ \\ ${ }^{1}$ Division of Physics, School of Medicine, University of Occupational and \\ Environmental Health, Japan. Yahatanishi-ku, Kitakyushu 807, Japan \\ ${ }^{2}$ Department of Lifescience, Faculty of Science, Himeji Institute of \\ Technology. Akoh-gun, Hyogo 678-12, JAPAN
}

Abstract: Proteoliposomes containing bacteriorhodopsin were attached to pre-formed phospholipid planar bilayers, and light-induced proton translocation by bacteriorhodopsin in $\mathrm{ms}$ time scale was monitored under an artificially imposed proton motive force. Upon illumination with a ms flash, the bilayer attached with bacteriorhodopsin-proteoliposomes generated a photocurrent which flowed from the liposome side (cis side) to the opposite side (trans side). A pre-illumination with multiple flashes, by which a backpressure of proton electrochemical potential was established across the liposome membrane, introduced a reversed current which was gated by light. Bacteriorhodopsin proteoliposomes made in an acidic buffer and attaches to a planar bilayer at neutral $\mathrm{pH}$ also showed a reversed photocurrent without pre-illumination. Moreover, a voltage supplied from an external source produced a negative current which was gated by light. From these results, we propose that there is a light-gated proton channel activity in bacteriorhodopsin. The approximate values of the unit conductance and the mean open time of the proposed proton channel are estimated to be 0.05 fS and $15 \mathrm{~ms}$, respectively.

Key words: bacteriorhodopsin, proton pump, ion channel, phospholipid planar bilayer.

(Received 13 August 1993, accepted 22 October 1993)

\section{Introduction}

Bacteriorhodopsin ( $\mathrm{bR}$ ) is the only protein found in the purple membrane of Halobacterium halobium [1]. Light absorbed by the retinal chromophore of bR initiates a photochemical cycle through a series of spectroscopically distinct intermediates, and during this photocycle protons are pumped out from the bacterial cell [2]. Thus bR, acting as a light-driven proton pump, converts light-energy into chemical free energy in the form of proton gradient (for review, see $[3,4,5])$. The elucidation of the molecular mechanism of the proton pumping remains to be challenged. 
Sone et al. [6] estimated the proton electrochemical potential generated by bR incorporated in proteoliposomes. The saturating potential under continuous illumination amounted to 210-220 $\mathrm{mV}$. Bamberg et al. [7] succeeded in recording the stationary photocurrent in the planar lipid bilayer on which bRs were transmembraneously incorporated. They showed that the magnitude of the stationary photocurrent, which approached zero at $-200 \mathrm{mV}$, was linearly dependent on the imposed voltage. Dancshazy et al. [8] reported that the decaying process of $\mathrm{M}_{410}$ photointermediate in $\mathrm{bR}$ was slowed when an electric potential was imposed on bR. The electric potential might be regulating the pumping efficiency by controlling the turnover rate of the photocycle [9]. Herrmann and Rayfield [10] proposed an electrical model of bR incorporated in liposomes in which the activity of the bR current generator was linearly dependent on the voltage.

The purpose of the present work was to investigate the bR proton pumping function by real time monitoring the $\mathrm{H}^{+}$movement in such an experimental condition where the pump is placed under a $\mathrm{H}^{+}$electrochemical potential gradient. For this purpose, we employed the electrical method first described by Drachev et al. [11], and further improved by Herrmann and Rayfield [10] and Bamberg et al. [7] ; purified bRs were reconstituted into liposomes with phospholipids, then the liposomes were attached to a planar lipid bilayer in the presence of $\mathrm{Ca}^{2+}$ ion. The electrical events that took place on illuminating the bR were recorded by an external electrical circuit.

We propose in this report that the illuminated bR not only works as a $\mathrm{H}^{+}$ pump but also mediates a passive flow of $\mathrm{H}^{+}$down an electrochemical potential gradient.

\section{Meterials and Methods}

Preparations - Halobacterium halobium $R_{1} M_{1}$ was grown and purple membranes were isolated as described [12]. Isolated purple membranes were suspended in distilled water and stored frozen at $-20^{\circ} \mathrm{C}$ until use.

Bacteriorhodopsin was reconstituted into liposomes with phospholipids at the protein: lipid ratio of $1: 40(\mathrm{~W} / \mathrm{W})$ by the sonication method as described [13], except that soybean phospholipid (asolectin) was used instead of egg PC. Asolectin was purchased from Associate Concentrates (Woodside, NY, USA) and partially purified as described [14].

Formation of the planar phospholipid bilayer - All procedures described below were carried out at room temperature $\left(22-25^{\circ} \mathrm{C}\right)$. A planar phospholipid bilayer was formed across an aperture (diameter $0.2 \mathrm{~mm}$ ) punched on a Teflon sheet 
(12.5 $\mu \mathrm{m}$ thick) which was separating two Teflon chambers (volume of the each chamber was $1.5 \mathrm{ml}$ with the surface area of $1 \mathrm{~cm}^{2}$ ) following the method described by Montal and Mueller [15]. To form planar bilayers, $15 \mu \mathrm{l}$ of asolectin dissolved in hexane $(10 \mathrm{mg} / \mathrm{ml})$ was placed on the surface of the buffer solution consisting of $0.2 \mathrm{M} \mathrm{KGl}, 20 \mathrm{mM}$ HEPES (pH7.2), and $5 \mathrm{mM}$ $\mathrm{MgCl}_{2}(0.5 \mathrm{ml}$ in each chamber $)$. Upon the evaporation of hexane, lipid monolayers were spontaneously formed at the air-water interface [16]. The water levels of the two compartments were then successively raised and the lipid monolayers were folded into a bilayer at the aperture. After forming the bilayer, a step voltage of $100 \mathrm{mV}$ was applied across the membrane to estimate the membrane resistance. Only those bilayers with a resistance greater than $200 \mathrm{G} \Omega$ were used for further studies.

Association of proteoliposomes containing bacteriorhodopsin to the planar lipid bilayer-The method described by Drachev et al. [11] was employed to attach bR-liposomes to the planar lipid bilayer. The association was initiated by a successive addition of bR-liposomes (final, $33 \mu \mathrm{g} \mathrm{bR} / \mathrm{ml}$ ) and $\mathrm{CaCl}_{2}$ (final, $30 \mathrm{mM}$ ) to one compartment (cis chamber) of the bilayer cell. The attachment of the liposomes to the bilayer was monitored by following the membrane capacitance change under continuous stirring [17].

Electrical recordings - The electric current flowing through the bilayer was converted to voltage by a laboratory-made I-V converter (an operational amplifier Teledyn 1035 combined with a $10 \mathrm{G} \Omega$ feedback resistor). The response time of the $\mathrm{I}-\mathrm{V}$ converter was $0.9 \mathrm{~ms}$. The cis and the trans chambers were connected to the external measuring circuit through agar bridges ( $2 \%$ agar in $3 \mathrm{M} \mathrm{KCl}$ ) and $\mathrm{Ag} / \mathrm{AgCl}$ electrodes. The $\mathrm{Ag} / \mathrm{AgCl}$ electrodes were wrapped in aluminum foil to protect from light and the artificial photoeffects were completely eliminated. The signal from the I-V converter was fed to a buffer amplifier and distributed to a monitoring scope, a strip chart recorder (YEW, TYPE 3066), and a wave memory (Autonics, S-210). The digitized signals from the wave memory were transferred to a computer (NEC, PC 9801) and stored in magnetic disks for later analysis.

Light sources - A $150 \mathrm{~W}$ projector lamp and a camera shutter (Capal, No. 0) were combined to give stepwise illuminations. A photoflash (National, Type 3650) was modified to give a pulsed light of $1 \mathrm{~ms}$ long. The discharge capacitor was $300 \mu \mathrm{F}$ energized to $350 \mathrm{~V}$. An orange filter (Toshiba VO-55) was used to select light with wavelengths longer than $530 \mathrm{~nm}$. The light was conducted to the bilayer cell by means of fiber optics. 


\section{Results}

Attachment of the reconstituted bacteriorhodopsin liposomes to the planar lipid bilayers The planar lipid bilayer did not give any photoresponse before and even after the addition of the $b R$ proteoliposomes. However, the bilayer became photoactive by adding $\mathrm{Ca}^{2+}$, indicating a tight association between the proteoliposomes and the underlining planar lipid bilayer $[7,10,11]$. The development of the photocurrent was accompanied by a decrease in the membrane capacitance (Fig. 1). The capacitance reached a plateau of 50$20 \%$ of the original value within $10 \mathrm{~min}$ after the addition of $\mathrm{Ca}^{2+}$. The magnitude of the photocurrent and the degree of the capacitance decrease were roughly proportional to each other (data not shown).

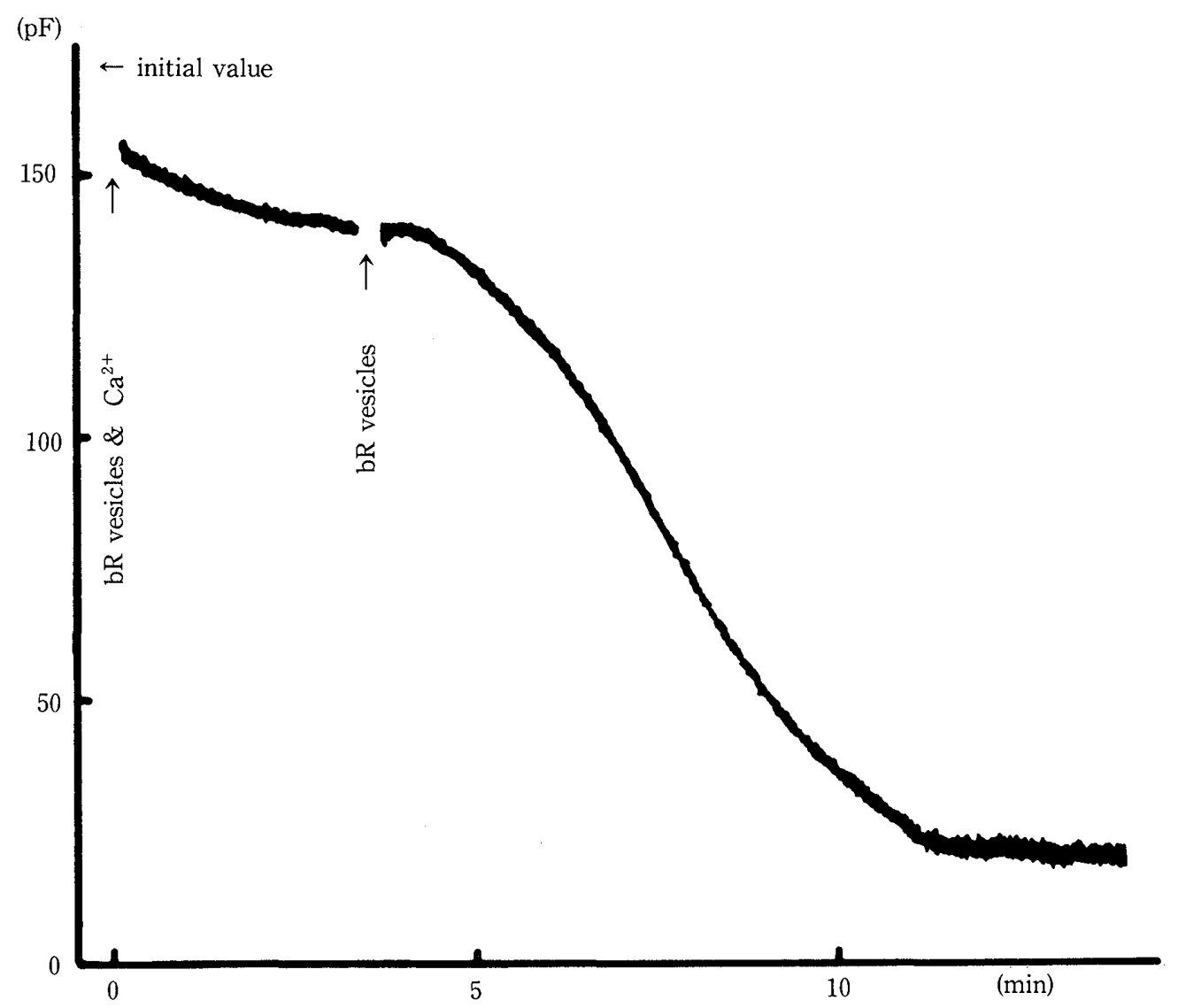

Fig. 1. Time course of the capacitance change of planar bilayer on addition of bR liposomes and $\mathrm{Ca}^{2+}$. Bacteriorhodopsin was reconstituted into liposomes by sonication in $0.5 \mathrm{M} \mathrm{KCl}$. Planar phospholipid bilayer was formed from the asolectin-hexane solution as described under Materials and Methods. Reconstituted bR liposomes $(50 \mu l)$ were then added to one of the chambers (cis chamber), followed by the addition of $50 \mu \mathrm{l}$ of $1 \mathrm{M} \mathrm{CaCl}_{2}$. The electrical capacitance of the bilayer was monitored by applying a $70 \mathrm{~Hz}, 2 \mathrm{mVpp}$ sinewave voltage across the membrane and measuring the $\mathrm{AC}$ current flowing through the membrane.

After the capacitance of the membrane reached a stationary level (usually $50-20 \%$ of the initial value), the cis chamber was perfused with the buffer without $\mathrm{Ca}^{2+}$ to remove extra liposomes and $\mathrm{Ca}^{2+}$. 


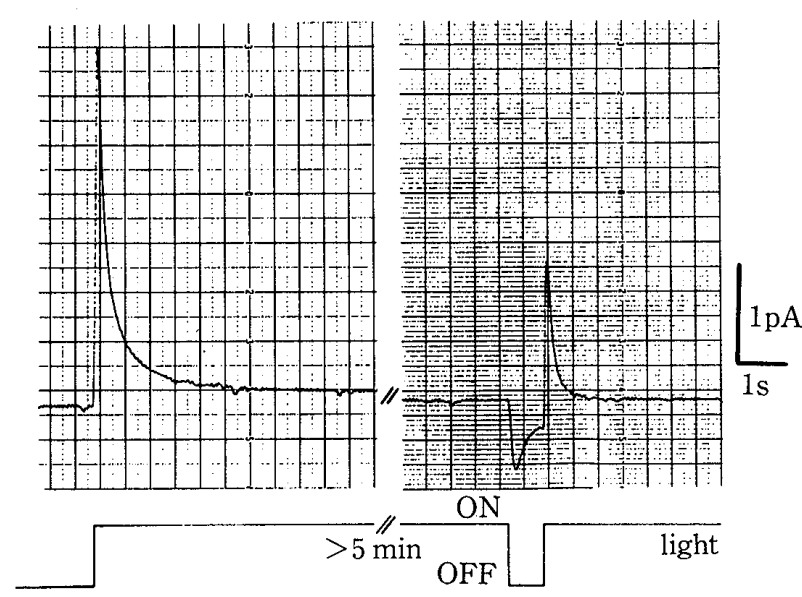

Fig. 2A

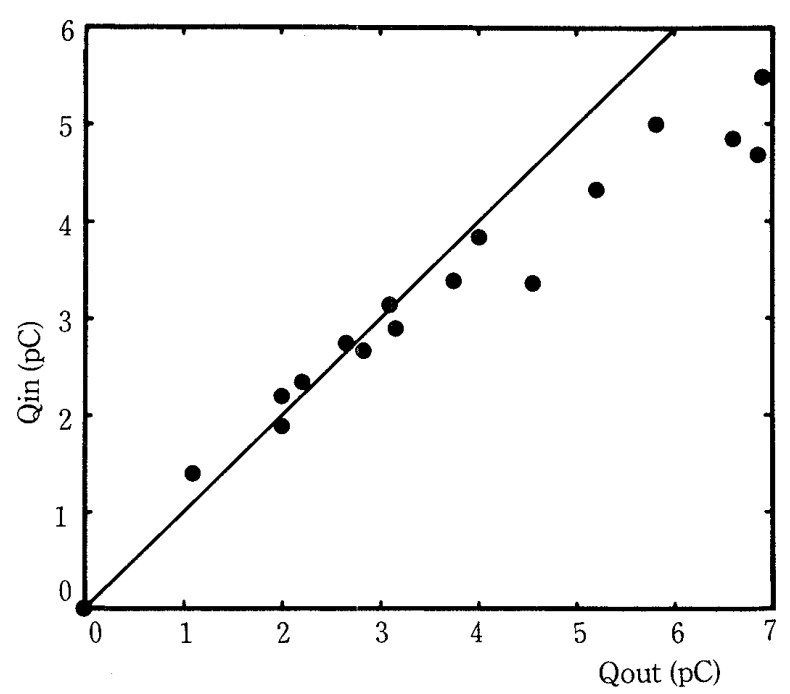

Fig. 2B

Fig. 2. Generation of photocurrent by $b R$ reconstituted into liposomes and bound to a planar phospholipid bilayer.

(A) Illumination was provided from a $150 \mathrm{~W}$ projector lamp. Illumination was started and stopped by a photoshutter. Upward deflection of the trace indicates the flow of a positive electric charge from the cis to the trans chamber.

(B) The planar bilayer with attached bR-liposomes was illuminated by continuous light for more than $5 \mathrm{~min}$ until the photocurrent reached a small steady level. Then the illumination was interrupted by a dark period (see Fig. 2A, right-side trace). $Q_{\text {out }}$ is the amount of the electric charge that flowed in a negative direction during the dark period. $Q_{i n}$ is the amount of the electric charge that flowed in a positive direction on re-started illumination. $Q_{i n}$ is plotted against $Q_{\text {out }}$ by varying the duration of the dark-period.

Both the membrane capacitance and the photoactivity remained unchanged after a complete removal of both extra liposomes and $\mathrm{Ca}^{2+}$ by perfusion with $\mathrm{Ca}^{2+}$-free buffer. Furthermore, the attachment of bR-liposomes to the bilayer seemed to be highly stable, since lowering the water level in the trans side below the aperture and the re-raising to reform the bilayer had essentially no effect on both the photoresponse and the membrane capacitance, which was in good contrast to the case of the $\mathrm{TF}_{0} \mathrm{~F}_{1}$-liposomes described previously [17]. The higher stability of the attached bR-liposomes compared to the $\mathrm{TF}_{0} \mathbf{F}_{1}$-liposomes might be due to the negatively charged lipid of purple membranes brought into the reconstituted liposomes.

Photoresponse to a stepwise illumination - The short-circuit photocurrent induced by a stepwise illumination is shown in Fig. 2A. The photocurrent was only transient, indicating that the current was mainly due to the intact bR-liposomes attached to the bilayer $[7,10]$. The direction of the photocurrent was from the cis to the trans side, which was as expected because the majority of the bRs were reconstituted into liposomes with their originally cytoplasmic side facing to 
the outside [18].

The peak photocurrent at the beginning of the step illumination varied from membrane to membrane and was $\sim 10 \mathrm{pA}$. The current decayed to a half of the peak value within $0.5 \mathrm{~s}$, followed by a slower decay approaching a stationary value of $\sim 0.05 \mathrm{pA}$. This residual small current is the leakage current through the planar bilayer at the saturating voltage (see Appendix).

When the light was turned off for a short period after a prolonged illumination ( $>5 \mathrm{~min}$ ), an electric current was produced which flowed in a negative direction (Fig. 2A, right side trace). On restarting the illumination, an electric current flowing in a positive direction reappeared. The amount of the electric charge that transported on restarted illumination was almost the same as the amout of the electric charge flowed in the dark period (Fig. 2B). This observation further supports the idea that the electric current produced by the illuminated planar bilayer is mainly due to the bR-liposomes bound to the bilayer.

Photocurrent induced by pulsed light - Photocurrent at the timescale of $\mathrm{ms}$ was obtained by replacing the light source with a Xe-filled flash lamp. The trace A in Fig. 3 shows the photocurrent recorded when the planar bilayer with attached-liposomes was illuminated by a ms flash. The half-time rise of the photocurrent was about $1 \mathrm{~ms}$, which probably reflects the response time of the recording circuit. The fast rise of the current was followed by a decay with a half-time of about $20 \mathrm{~ms}$. This decay time is comparable with the half-time of the proton uptake at the cytoplasmic side of $\mathrm{bR}$ measured with a $\mathrm{pH}$-indicator dye [18].

A drastic change in the flash-induced current was observed when the sampling light pulse was preceded by multiple flashes. As shown in trace B in Fig. 3 , the photocurrent recorded after a pre-illumination transiently moved in a negative direction. The net effect of the pre-illumination was obtained by subtracting the trace $\mathrm{A}$ from the trace $\mathrm{B}$ in Fig. 3. The result is shown in trace $\mathrm{C}$. The difference in the currents was negative (from the liposome interior to the outside) and the timeconstant of the decay was $\sim 15 \mathrm{~ms}$.

The modulated photocurrent as shown in trace $\mathrm{B}$ returned to the original shape as trace A when the illuminated bilayers were placed in the dark (Fig. 3). The half-time of the recovery was about $20 \mathrm{~s}$. This recovery time is much shorter than the time of dark-adaptation [19], and is much longer than the lifetime of any photointermediate of bR [4]. Hence, neither the accumulation of photointermediate(s) of $\mathrm{bR}$ nor the light/dark adaptation of $\mathrm{bR}$ is appropriate to explain the pre-illumination effect. Rather, it is most likely that the back pressure of the proton motive force created by the pre- 
illumination across the liposome membrane is the cause of the negative current. Actually, a measurement by a glass $\mathrm{pH}$-electrode showed that the $\mathrm{pH}$ changes of the bR-liposome suspension produced by flash-excitation decayed with a halftime of $20 \mathrm{~s}$ [11]. The results of the following experiments, that is, one with a preformed $\mathrm{pH}$ difference across the liposome membrane, and the other under the externally applied voltage seem to support the above explanation.

$p H$ difference across the liposome membrane generates a reversed current which is gated by light - The trace A in Fig. 4 shows the photocurrent where the inside of the attached liposome was buffered at $\mathrm{pH} 5.5$ and the outside $\mathrm{pH}$ was kept at 7.2.
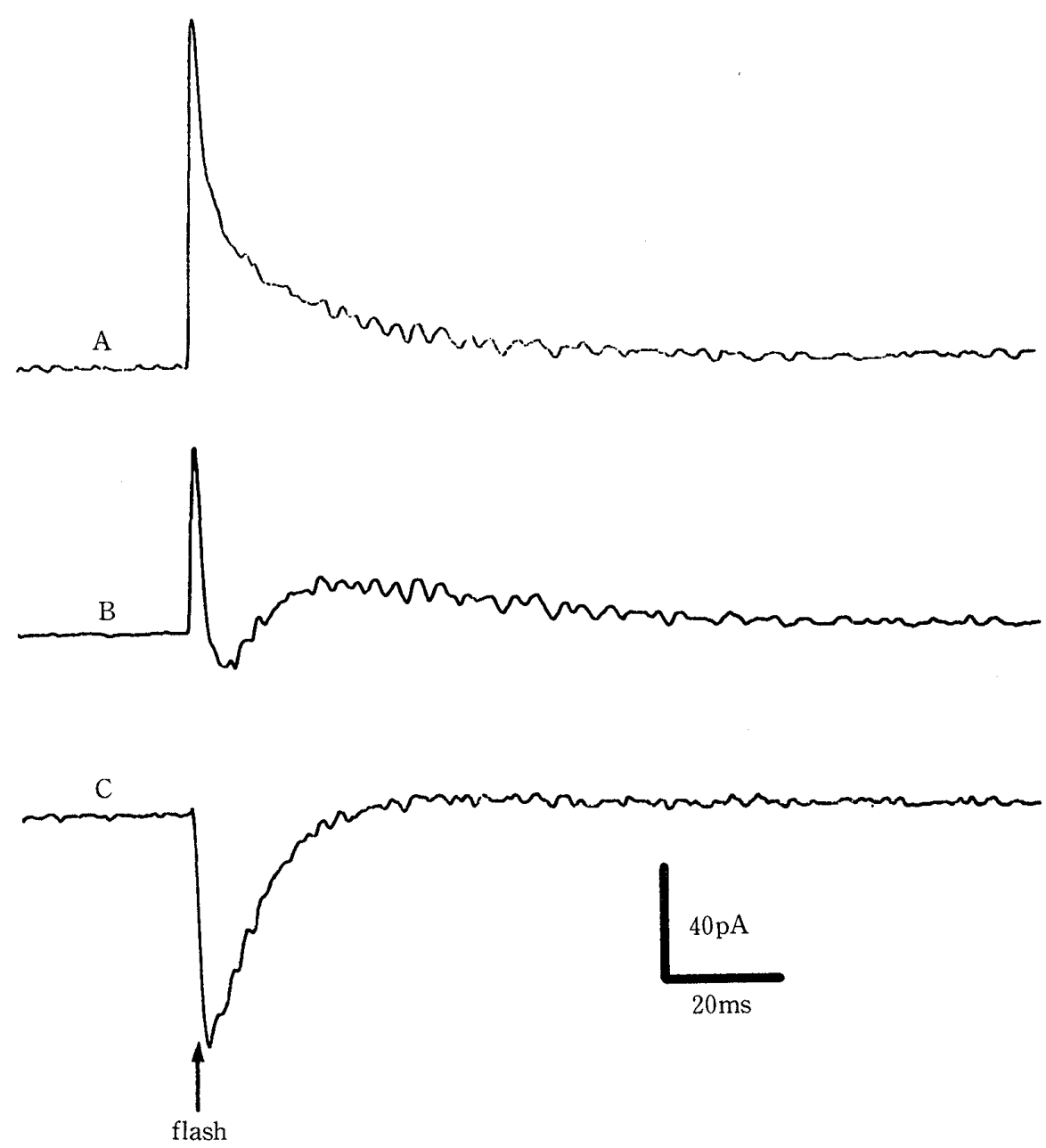

Fig. 3. Effect of pre-illumination on the photocurrent

Planar phospholipid bilayer was formed and $\mathrm{bR}$ proteoliposomes were adsorbed on it as in Fig. 1. Illumination was from a photoflash of $1 \mathrm{~ms}$ long.

(A) The cis chamber was electrically connected to the ground level and the photocurrent induced by the pulsed light was recorded. The membrane was kept in the dark for 3 min prior to the sampling flash.

(B) The membrane was illuminated by a train of light pulses with intervals of $3 \mathrm{~s}$ (11 pulses), and the photocurrent induced by the last one was recorded.

(C) The difference between the trace in (B) and that in (A). 
Under this condition, the shape of the photocurrent was similar to the trace B in Fig. 3. Furthermore, a pre-illumination with multiple flashes in addition to the pre-formed $\mathrm{pH}$ difference made the reversed current much deeper (trace $\mathrm{B}$ of Fig. 4). In a control experiment where the $\mathrm{pH}$ of the outside medium was made the same as that of the liposome interior ( $\mathrm{pH} \mathrm{5.5),} \mathrm{the} \mathrm{flash-induced}$ current deflected in a positive direction and the current shape was as in trace A of Fig. 3.
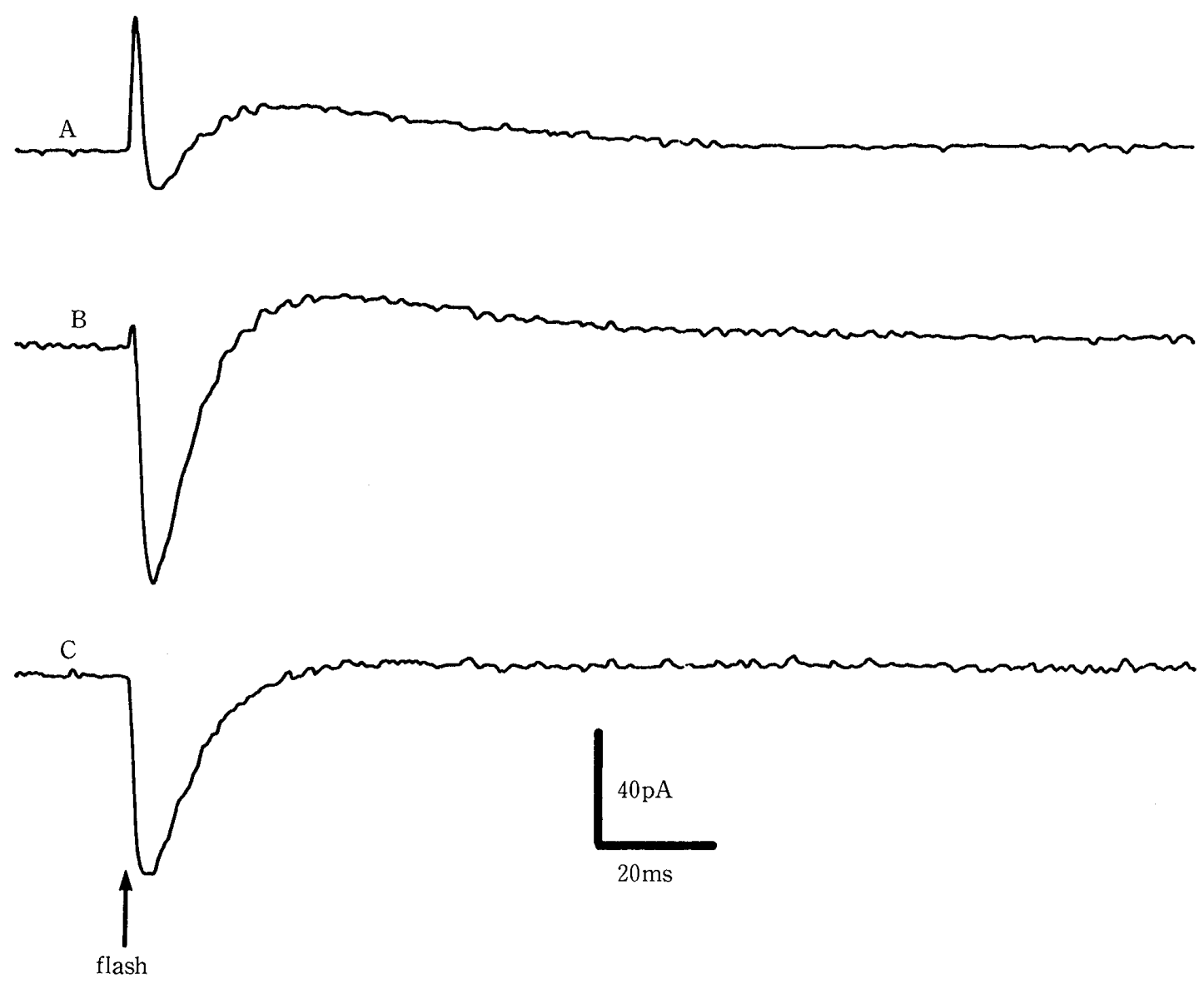

Fig. 4. Effect of the pre-formed $\mathrm{pH}$ gradient across the liposome membrane on the photocurrent. Formation of the planar phospholipid bilayer and adsorption of $\mathrm{bR}$ proteoliposomes were as in Fig. 1, except that the liposomes were made in $0.5 \mathrm{M} \mathrm{KCl}, 50 \mathrm{mM}$ potassium phosphate ( $\mathrm{pH} 5.5)$ to make the liposome interior acidic and heavily buffered. A buffer solution consisting of $0.2 \mathrm{M} \mathrm{KCl}, 5 \mathrm{mM} \mathrm{MgCl}{ }_{2}, 20 \mathrm{mM}$ HEPES ( $\mathrm{pH}$ 7.2) was used for bilayer formation and perfusion.

(A) BR liposomes made in the acidic buffer were adsorbed on the planar bilayer formed at neutral pH. The photocurrent induced by a single light pulse was recorded.

(B) The planar membrane was illuminated by multiple light pulses prior to the sampling flash. The photoresponse to the 11th flash was recorded as in Fig. 3.

(C) The difference between the trace in (B) and that in (A). 
Externally applied electric potential modulates the photocurrent - The photocurrent was modulated by the externally applied electric potential difference (Fig. 5). The positive voltage (more positive in the cis chamber) enhanced the magnitude of the photocurrent (trace A) while a negative potential suppressed it (trace $\mathrm{C}$ ). As shown in trace $\mathrm{C}$, at a holding potential of $-150 \mathrm{mV}$, illumination by a
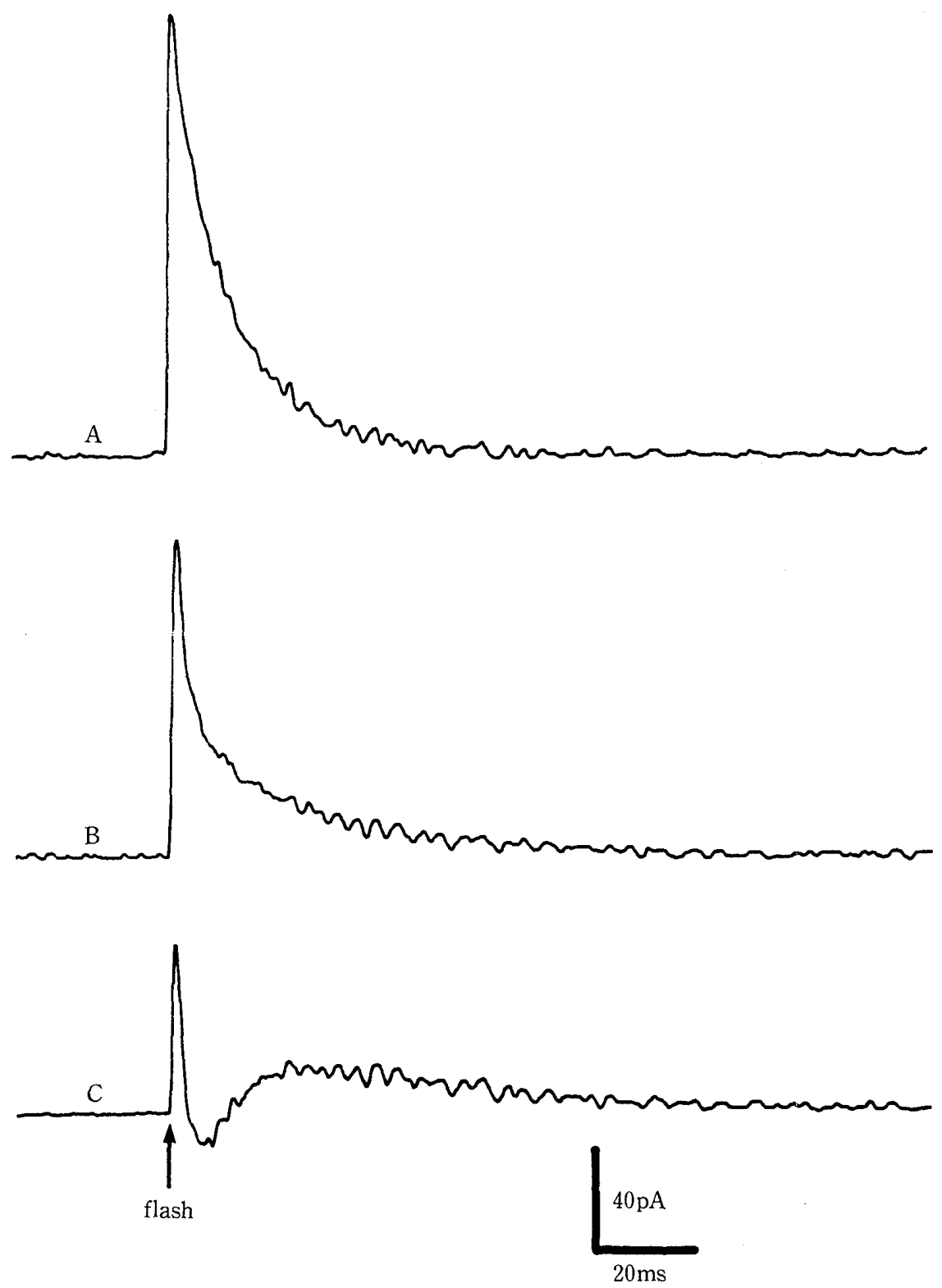

Fig. 5. Effect of the externally applied electric potential on the photocurrent

Planar phospholipid bilayer was formed and bR liposomes were attached on it as in Fig. 1.

The voltage of the cis chamber was varied by an external voltage source keeping the trans chamber at virtual ground level.

(A) The cis chamber was kept at $+200 \mathrm{mV}$.

(B) The cis chamber was kept at $0 \mathrm{~V}$.

(C) The cis chamber was kept at $-150 \mathrm{mV}$. 


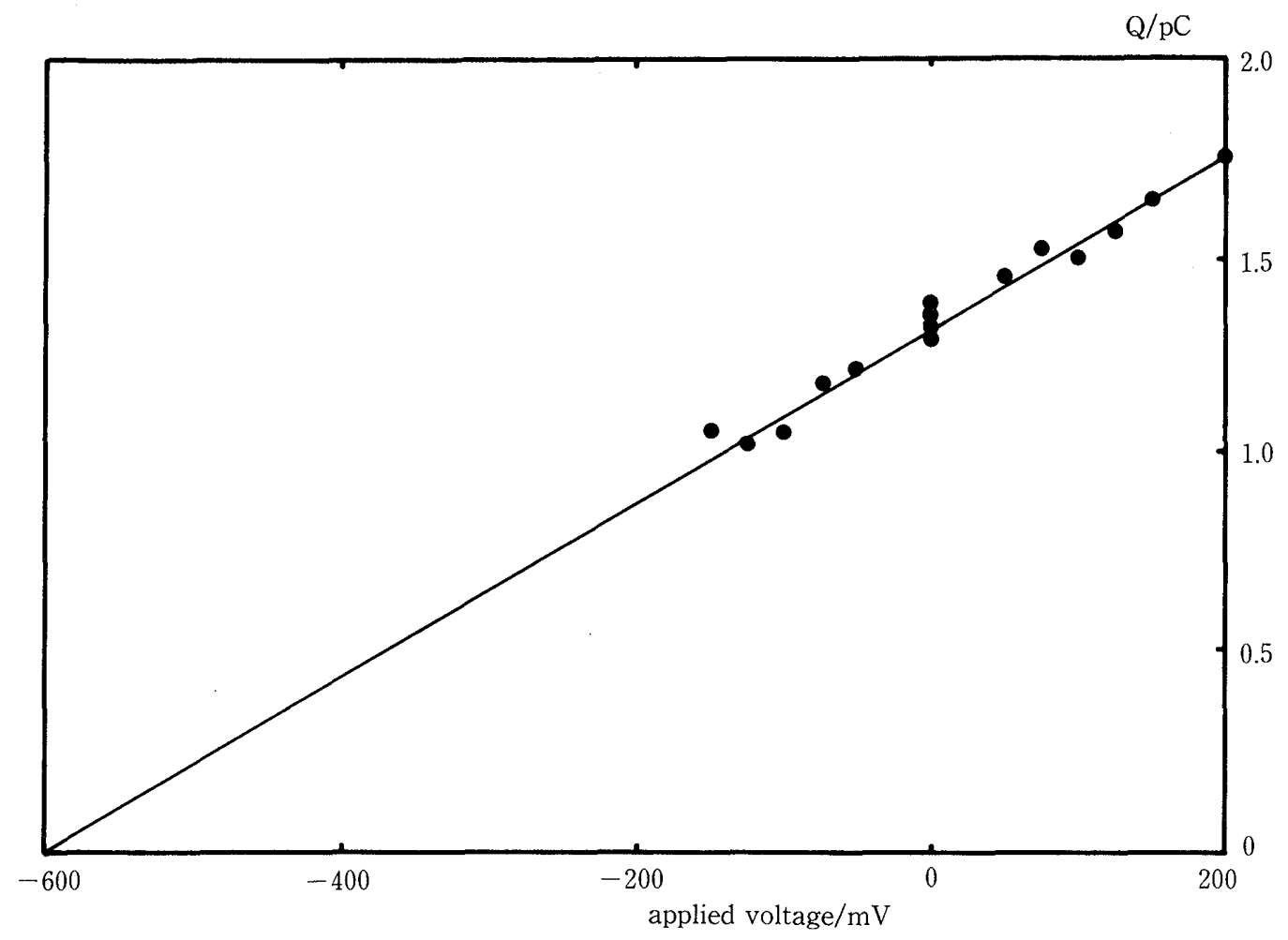

Fig. 6. The amount of the transported charge as a function of the external voltage The planar phospholipid bilayer was formed and $b R$ liposomes were attached on it as in Fig. 1. An electric potential difference was imposed on the planar membrane by raising and lowering the voltage of the cis chamber keeping the trans chamber at the virtual ground level. The flash-induced photocurrent at each voltage was recorded. The membrane was kept in the dark for $3 \mathrm{~min}$ before each sampling flash.

The net electric charge that was transported in a positive direction within the period of $180 \mathrm{~ms}$ after the flash was calculated and plotted against the imposed voltage.

single flash produced a reversed current. We could not impose voltages greater than $200 \mathrm{mV}$ in absolute value, because at higher voltages the bilayer became unstable.

The amount of the total electric charge $Q$ translocated from the cis to the trans chamber on single flash excitation is shown in Fig. 6 as a function of the externally applied voltage, $V_{\text {ext }}$. As shown, $Q$ was found to be linearly dependent on $V_{e x t}$. $\quad Q$ becomes zero at $V_{e x t}=-600 \mathrm{mV}$.

\section{Discussion}

Photocurrent under proton motive force - The purpose of the present work was to study the proton pumping activity of $\mathrm{bR}$ in conditions where the pump was placed under a proton motive force. The proton motive force was formed across the liposome membrane by preillumination (Fig. 3), in the form of $\mathrm{pH}$ 
difference (Fig. 4) and by imposing an electric potential from an external voltage source (Fig. 5).

A quite interesting observation was that the photocurrent transiently moved in a negative direction on illuminating $b R$ placed under a proton motive force against the bR pump (a proton back pressure). As described in the appendix, the negative current indicates the flow of positive charge from the liposome interior to the outside, a direction opposite to the bR pumping. As seen in Fig. 4, a pure $\mathrm{pH}$ difference across the liposome membrane was enough to generate the (light-induced) reversed current. Thus it is most likely that, among other ions, the flow of protons down the electrochemical potential gradient causes the negative current.

The photointermediate(s) responsible for the reversed current-An important point to be noted is that the passive negative current as well as the pumped current was initiated by light, indicating that the photointermediate $(\mathrm{s})$ of $\mathrm{bR}$ is mediating the passive flow of proton. The decay time of the passive current was about $15 \mathrm{~ms}$, which is comparable with the lifetime of $\mathrm{M}_{410}$ [18]. Hence, among the photointermediates of $\mathrm{bR}$, the intermediate $\mathrm{M}_{410}$ seems to be responsible for the passive current. The passive conduction of protons through the bRpathway is thought to be ohmic, because the magnitude of the light-induced current was proportional to the externally applied voltage (Fig. 6). Since bR is designed to work as a light-induced proton pump, it seems natural that there exists a proton permeable pathway in the bR protein [20]. In fact, it is widely accepted that the retinal Schiff base of $\mathrm{bR}$ undergoes a protonation/ deprotonation cycle during the photocycle of bR [4]. Engelhart et al. [21], using a static and time-resolved infrared difference spectroscopy, observed the protonation changes of four aspartic acids during the proton pumping photocycle of bR.

We previously pointed out a possibility that the blue light makes bR leaky to protons [18]. In the present experiment, however, the possibility of the "blue-light effect" is excluded, since the exciting flash did not contain light with wavelengths shorter than $530 \mathrm{~nm}$.

From the above considerations, we propose that $\mathrm{bR}$, when illuminated, not only works as a proton pump but also forms a proton selective pathway, a proton channel.

Observation of ion channel activity in an ion pump is not exceptional. Okamoto et al. [22] purified the membrane-integrated portion $\left(\mathrm{TF}_{0}\right)$ of the proton translocating ATPase from thermophilic bacterium PS3. They measured the $\mathrm{H}^{+}$-conducting activity of $\mathrm{TF}_{0}$ in liposomes reconstituted from $\mathrm{TF}_{0}$ and phospholipids. They showed that $\mathrm{TF}_{0}$ works as a $\mathrm{H}^{+}$selective 
channel with a unit conductance of $0.16 \mathrm{fS}$ at $\mathrm{pH} 6$. Last et al. [23] incorporated $\left(\mathrm{Na}^{+}, \mathrm{K}^{+}\right)$-ATPase from the kidney into a planar lipid bilayer and showed that $\left(\mathrm{Na}^{+}, \mathrm{K}^{+}\right)$-ATPase conferred ion channel activity on the planar bilayer. More recently, Mirovoba et al. incorporated a large subunit of $\left(\mathrm{Na}^{+}, \mathrm{K}^{+}\right)$-ATPase into bilayer lipid membranes and showed that the subunit formed ion channels in the membrane. They further reported that the channels are activated by ATP, sensitive to ouabain, and selective for monovalent cations. Konishi and Packer [24] investigated $\mathrm{H}^{+}$diffusion across liposomes reconstituted from bleached bR. They showed that the diffusion was faster in bleached bR than in regenerated bR. They claimed that $\mathrm{bR}$ has a $\mathrm{H}^{+}$conducting channel.

Characterization of the proposed $b R H^{+}$channel - Ion channels in biological membranes are characterized by their selectivity between ionic species, mean open time and unit conductance [25]. Some ion channels are gated by the change in the membrane potential [26] and some are gated by the binding of specific ligands $[27,28]$. To the best of our knowledge, the present work is the first one reporting the light-gated ion channel.

Finally, we roughly characterize the bR $\mathrm{H}^{+}$channel. The mean open time $\tau$ of the channel is estimated from the decay kinetics of the passive current (the trace $\mathrm{C}$ in Fig. 3) to be $15 \mathrm{~ms}$. To estimate the unit conductance $g$ of bR $\mathrm{H}^{+}$channel, we need to know the number $N$ of bR involved and the amount of charge $Q$ passively transported under a voltage $V$; then the unit conductance is given as $g=Q /(N V \tau)$.

As calculated in the Appendix, the amount of the charge $Q=0.9 p C$ at $V=$ $50 \mathrm{mV}$ and the number $N$ of bR molecules taking part in the pumping is $2.4 \times$ $10^{7}$ in a typical bilayer preparation. From these values, we get $g=0.05 \mathrm{fS}$.

\section{Acknowledgment}

Part of this work has been supported by Grants-in-Aid No. 01617003, No. 01480497, No. 01300009 and No. 02808050 from the Japanese Ministry of Education, Science and Culture.

\section{References}

1. Oesterhelt D \& Stoekenius W (1971): Rhodopsin-like protein from the purple membrane of Halobacterium halobium. Nature 223: 149-152.

2. Oesterhelt D \& Stoeckenius W (1973): Functions of a new photoreceptor membrane. Proc Natl Acad Sci USA 70: 2853-2857

3. Henderson R (1977): The purple membrane from Halobacterium halobium. Ann Rev Biophys 
Bioeng: 87-109

4. Stoeckenius W, Lozier R H \& Bogomolni R A (1979): Bacteriorhodopsin and the purple membrane of halobacteria. Biochim Biophys Acta 505: 215

5. Stoeckenius W \& Bogomolni R A (1982): Bacteriorhodopsin and the related pigments of Halobacteria. Ann Rev Biochem 52: 587-616

6. Sone N, Takeuchi M, Yoshida $M$ et al (1977): Formation of electrochemical proton gradient and adenosine triphosphate in proteoliposomes containing purified adenosine triphosphatase and bacteriorhodopsin. J Biochem 82: 1751-1758

7. Bamberg E, Dencher A, Fahr A et al (1981): Transmembraneous incorporation of photoelectrically active bacteriorhodopsin in planar lipid bilayers. Proc Natl Acad Sci USA 78: 7502-7506

8. Dancshazy Zs, Helgerson S L \& Stoeckenius W (1983): Coupling between the bacteriorhodopsin photocycle kinetics and proton motive force. I. Single flash measurements in Halobacterium halobium cells. Photobiochem Photobiophys 5: 347-357

9. Westerhoff H V \& Dancshazy Zs (1984): Keeping a light-driven proton pump under control. Trends Biochem 3: 112-117

10. Herrmann T R \& Rayfield G W (1978): The electrical response to light of bacteriorhodopsin in planar membranes. Biophys J 30: 231-241

11. Drachev L A, Josaitis A A, Kaulen A D (1974): Direct measurement of electric current generation by cytochrome oxidase, $\mathrm{H}^{+}$-ATPase and bacteriorhodopsin. Nature 249: 321-324

12. Becher B M \& Cassim J Y (1975): Improved isolation procedures for the purple membrane of Halobacterium halobium. Prep Biochem 5:6r161-178

13. Govindjee R, Ebrey T G \& Crofts A R (1980): The quantum efficiency of proton pumping by the purple membrane of Halobacterium halobium. Biophys $\mathrm{J} \quad 30: 231-242$

14. Sone N, Yoshida M, Hirata $H$ et al (1977): Reconstitution of vesicles capable of energy transformation from phospholipids and adenosine triphosphatase of a thermophilic bacterium. J Biochem (Tokyo) 81: 519-528

15. Montal M \& Mueller P (1972): Formation of bimolecular membranes from lipid monolayer and a study of their electrical properties. Proc Natl Acad Sci USA 69: 3561-3566

16. Schindler $H$ (1980): Formation of bilayers from artificial or native membrane vesicles. FEBS Lett 122: $77-79$

17. Hirata H, Ohno K, Sone N, et al (1986): Direct measurement of the electrigenicity of the $\mathrm{H}^{+}$-ATPase from thermophilic bacterium PS3 reconstituted in planar phopholipid bilayers.

J Biol Chem 261: 9839-9843

18. Ohno K, Govindjee R \& Ebrey T G (1983): Blue light effect on proton pumping by bacteriorhodopsin. Biophys J 43: 251-254

19. Ohno K, Takeuchi Y, and Yoshida M (1977): Effect of light-adaptation on the photoreaction of bacteriorhodopsin from Halobacterium halobium. Biochim Biophys Acta 462: 575-582

20. Nagle J F \& Tristram-Nagle S (1983): Hydrogen bonded chain mechanisms for proton conduction and proton pumping. J Memb Biol 74: 1-14

21. Engelhart M K, Gewwert K, Hess B, (1985): Light-driven protonation changes of internal aspartic acids of bacteriorhodopsin: An investigation by static and time-resolved infrared difference spectroscopy using $\left[4-{ }^{13} \mathrm{C}\right]$ aspartic acid labeled purple membrane. Biochemistry 24: $400-407$

22. Okamoto M, Sone N, Hirata $\mathrm{H}$ et al (1977): Purified proton conductor in proton translocating adenosine triphosphatase of a thermophilic basterium. J Biol Chem 252: 6125-6131 
23. Last T A, Gantzer M L Tyler C D (1983): Ion-gated channel induced in planar bilayers by incorporation of $\left(\mathrm{Na}^{+}, \mathrm{K}^{+}\right)$-ATPase. J Biol Chem 258: 2399-2404

24. Konishi T \& Packer L (1978): A proton channel in bacteriorhodopsin. FEBS Lett 89: $333-336$

25. Sakmann M \& Neher E (ed). (1983): Single-Channel Recording. Plenum Press, New York $503 \mathrm{pp}$

26. Catterall W A (1988): Structure and function of voltage-sensitive ion channels. Science 242: $50-61$

27. Olsen R W \& Tobin A J (1990): Melecular biology of GABA receptors. FASEB J 4: $1469-1480$

28. Boulter J, Hollmann M, O'Shea-Grennfield A et al (1990): Molecular cloning and functional expression of Glutamate recptor subunit genes. Science 249: 1033-1037

\section{Appendix}

\section{(1) Electrical equivalent circuit model}

The electrical response to the light of bR-liposomes adsorbed on planar membranes was analyzed by Hermann \& Rayfield (10) in terms of an electrical equivalent circuit model. A schematic drawing of a bR-liposome adsorbed on a planar membrane is shown in Fig. 7 along with the equivalent electrical circuit, which is basically the same as in (10) except that the resistance of the proton pathway in $\mathrm{bR}, R_{\mathrm{bR}}$, is introduced here. The current $i_{e}$ recorded on the external circuit is a combination of two contributions, the capacitive current through $C_{m}$ and the leakage current through $R_{m}$;

$$
i_{e}=C_{m} d V / \mathrm{dt}+V / R_{m}
$$

In the dark equilibrium, $V=\mathrm{d} V / \mathrm{dt}=0$ hence $i_{e}=0$. Upon illumination, the bR current generator, $i_{p}$, starts to work resulting in a development of the potential $V$ across the liposome membrane;

$$
C \mathrm{dV} / \mathrm{dt}+V / R=i_{p}
$$

where $\mathrm{G}=C_{V}+C_{m}$ and $1 / R=1 / R_{v}+1 / R_{m}$. The formation of $V$ in turn generates a current $i_{e}$ through the external ammeter. On prolonged illumination, the potential $V$ approaches a saturating value, say $200 \mathrm{mV}$, and the capacitive current dies away $(\mathrm{d} V / \mathrm{dt}=0)$ leaving only the leakage current. As described in Results, the magnitude of the capacitive current at the beginning of a step illumination was $\sim 10 \mathrm{pA}$ and the leakage current was $\sim 0.05 \mathrm{pA}$ in a typical recording.

The photoresponse of the bR-liposome/bilayer system to a pulsed light takes place in the time scale of $10-20 \mathrm{~ms}$ (see Results). In this short time 


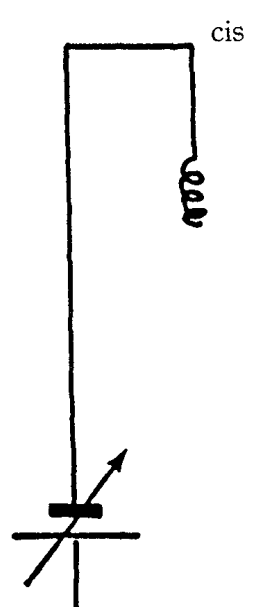

cis
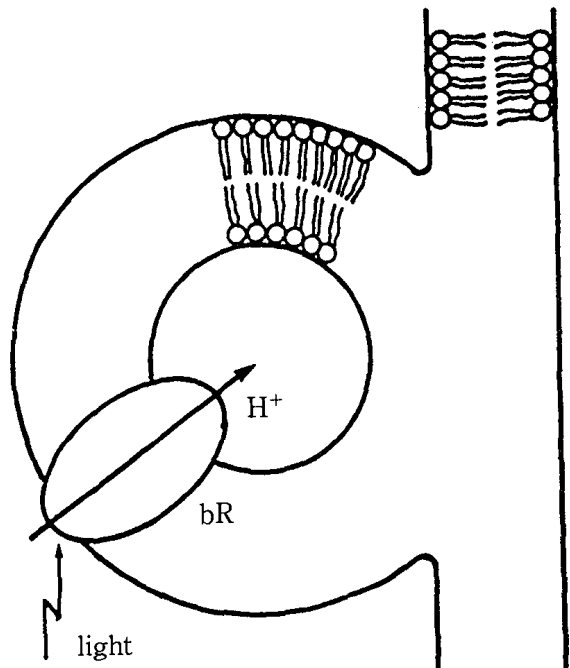

BLM

(A)

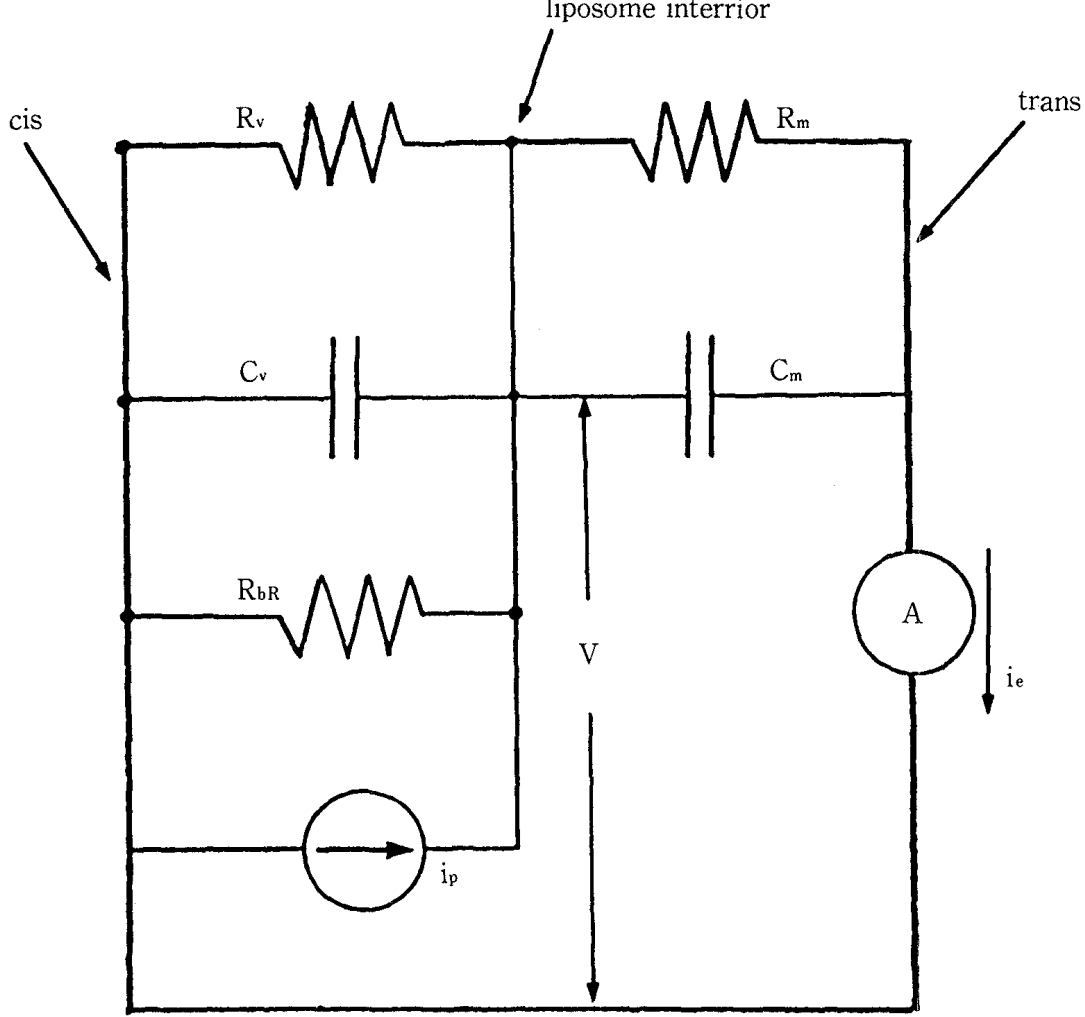

(B)

Fig. 7. A schematic description of $b R$ liposomes adsorbed on planar membrane (A) and its equivalent circuit (B).

The symbols are; $R_{v}$ and $C_{v}$; resistance and capacitance of the adsorbed bR liposome. $R_{m}$ and $C_{m}$, resistance and capacitance of bR-liposome/planar membrane junction. $V$; voltage across the liposome membrane. $i_{p}$; the electric current generated by the bR pump. $i_{e}$; the electric current recorded by the external measuring circuit. And $R_{\mathrm{bR}}$ denotes the resistance of the $\mathrm{bR}$ proton pathway which transiently opens on illumination (see Discussion). 
scale, the contribution of the capacitive current is predominant and we can neglect the contribution of the leakage current [10]. Then from Eqs. [Al] and [A2], we get;

$$
i_{e}=\left(C_{m} / C\right) i_{p}
$$

Hence the current $i_{e}$ recorded on the external circuit faithfully reproduces the $\mathrm{bR}$ photocurrent across the liposome membrane; only the magnitude is reduced by a factor $C_{m} / C$. The movement of a positive charge into the liposome interior appears as an electric current flowing from the cis to the trans chamber through the planar bilayer.

\section{(2) Estimation of the number $N$ of bR participating in pumping}

We try to calculate the unit conductance using the result shown in Fig. 6. For the calculation of $N$, we will take advatage of the knowledge that the net $\mathrm{H}^{+}$transport by bR-pump is completely suppressed when the pump is placed under a proton motive force of about $-200 \mathrm{mV}[6,7]$. The voltage dependence of the photocurrent shown in Fig. 6 tells us that an external boltage of $-600 \mathrm{mV}$ will stop the photocurrent. This in turn indicates that about $1 / 3$ of the externally applied voltage was actually imposed on $b R$ in the attached liposomes. Hence we get $R_{v} / R_{m}=1 / 2$.

Then, we assume that the time constant, one of the basic electrical constants of the bilayer, of bR-liposomes and that of the planar bilayer are the same.

$$
R_{v} C_{v}=R_{m} C_{m}
$$

Then, we get $C_{m} / C_{v}=2$, hence $C_{m} / C=1 / 3$. Finally from [A3], we obtain a relation between the pumped current $i_{p}$ and the recorded current $i_{e}$;

$$
i_{e}=i_{p} / 3
$$

From the trace in Fig. 6, we can estimate the amount of the charge transported through the external measuring circuit induced by a single flash. When the applied voltage is zero, it is $\sim 1.3 \mathrm{pG}$, and when the applied voltage is $-150 \mathrm{mV}$, it is $\sim 1.0 \mathrm{pC}$. From [A5], the amount of the charge transported by the bR pump is 3 times as large as the charge measured by the external circuit. Hence at zero volt, bR pumped $Q_{0}=3.9 \mathrm{pC}$ and $3.0 \mathrm{pC}$ at $-50 \mathrm{mV}$ (i. e. under the external voltage of $150 \mathrm{mV}$ ). The difference, $0.9 \mathrm{pG}$, is the charge transported passively down the electromotive force through the $b R$. From $Q_{0}$ we can estimate the number $N$ of bR involved in the pumping. 
Since a bR transports one proton per cycling, the number $N$ can be estimated as;

$$
N=Q_{0} / q
$$

where, $\mathrm{q}=1.6 \times 10^{-19} \mathrm{C}$ (the unit charge). From [A6], we estimate $N \sim 2.4 \times 10^{7}$.

バクテリオロドプシンには光によって開くプロトンチャンネルの活性がある

大野 宏毅 ${ }^{1}$, 平田 肇

1産業医科大学物理学教室 2姬路工業大学理学部生命科学科

要旨： バクテリオロドプシン（bR） は高度好塩菌 Halobacteriumu halobium の紫膜に存在す る唯一の膜タンパク質であり, 光駆動型プロトンポンプ（光を受けて水素イオンを 細胞内から細胞外へと輸送する）として知られている。この実験の目的は， bR がプ ロトンの電気化学的ポテンシャル勾配下に置かれたときどのように振る舞うかを調 べることであった。この目的のために脂質平面膜法を応用した電気的測定法を適用 した， bR をリン脂質小胞に再構成したのち，脂質平面膜に組み込んだ。 $\mathrm{bR}$ ポンプ

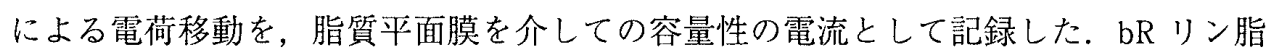
質小胞と脂質平面膜との結合は強固で，長時間にわたって安定な記録が可能であっ た。われわれの実験装置で（平面膜の直径 $200 \mu \mathrm{m}$ )，ミリ秒の閃光照射によって $200 \mathrm{pA}$ 程度のパルス電流が観察された. プロトンの電気化学的ポテンシャル勾配を 以下の 3 種の方法で生成した. 1) あらかじめ bR ポンプを長時間照射してほとんど 飽和に達するプロトン勾配を生成する，2）リン脂質小胞内を酸性にしてポンプと逆 向きの $\mathrm{pH}$ 勾配を保持する，3）外部電源から平面膜に電圧を印加する.

どの方法を採用しても，加えられたポテンシャル勾配がポンプの向きと逆向きの 場合は本来のポンプ電流に加えて，一過性の負電流が観察された。さらに，外部電 圧（方法 3）を加えると, bR によって輸送される電荷の総量は電圧に線形に依存し て変化した，観察結果を総合すると，bRには光によってゲートの開くプロトンチャ ンネルとしての作用があることが強く示唆される。チャンネルの平均開口時間はお よそ $15 \mathrm{~ms}$ ，チャンネル 1 個あたりのコンダクタンスはおよそ 0.05 fS と推定した.

J UOEH（絠業医大誌） 16 (1) : 1-17 (1994) 